\title{
Kritisk og upartisk? Utilsiktet religionskritikk i larebøker for KRLE
}

\begin{abstract}
Av Geir Winje
I denne artikkelen undersøkes fem larebøker i KRLE med tanke på om, og eventuelt hvordan, de formidler religionskritikk samtidig som de formidler religionskunnskap. Et hovedfunn er at larebøkene eller utgiverne så å si aldri formulerer direkte kritikk av religionene, scrlig ikke når det gjelder trosforestillinger. De kan imidlertid røpe en kritisk holdning til religionene i faget når det kommer til etikk og verdispørsmål, men $i$ stedet for å formulere denne kritikken på en tydelig måte, antydes den - ofte ved å lede leserens oppmerksomhet $i$ retning av det som er kritikkverdig. Jeg gir også eksempler på at lærebøkene kan omhandle problematiske forestillinger og praksiser uten å antyde dette for leserne. Til sist viser jeg hvordan KRLE-bøkene kan synes å kritisere religioner indirekte ved å tillegge dem en lav grad av relevans eller historisitet.
\end{abstract}

Nøkkelord: lærebøker, KRLE, religionskritikk, religioner

Geir Winje (1955) dosent, Høgskolen i Sørøst-Norge, Postboks 235, 3603 Kongsberg.

E-post: Geir.Winje@ usn.no

\section{INNLEDNING}

Denne artikkelen handler om religionskritikk, men ikke som på 1800- og tidlig 1900-tall, da historie- og naturvitenskap stadig lanserte funn som utfordret religionenes historieforståelse og ontologi. Artikkelen undersøker den kritikken elevene kan møte i lærebøkene sine, både hva bøkene kritiserer og hvordan kritikken kommer til uttrykk. Begrepet kritisk (fra gresk) har grunnbetydning «skjelnende», men brukes her primært som «vurderende». Med kritikkverdig menes altså noe som vurderes negativt i henhold til visse kriterier.

Artikkelen er organisert i tre deler: I den første delen tar jeg for meg bakgrunnen for unders $\emptyset$ kelsen og formulerer en problemstilling. Jeg plasserer artikkelen i forhold til annen lærebokforskning og gjør rede for metodiske og andre valg. I den andre delen analyserer jeg utdrag fra fem lærebøker i KRLE for femte årstrinn, og i del 3 oppsummerer jeg de viktigste funnene. ${ }^{1}$

Artikkelen rangerer ikke lærebøkene og kårer ingen « vinner». Den vurderer ikke bøkene opp imot hverandre, men forholder seg til hele tekstmassen samlet. Lærebokforfatterne har en vanskelig oppgave når de skal forklare kompliserte

1 Når jeg skriver generelt om faget, bruker jeg i hovedsak dagens betegnelse (KRLE; kristendom, religion, livssyn og etikk) synonymt med de tidligere navnene (KRL; kristendomskunnskap med religions- og livssynsorientering, KRL; kristendom, religion og livssyn, og RLE; religion, livssyn og etikk).

Prismet - IKO-Forlaget 2018

Tilgjengelig på https://journals.uio.no/index.php/prismet. Publisert under CC BY-NC 4.0. 
religiøse forestillinger og verdier på et begrenset antall sider, og den er nesten umulig dersom de også skal gjøre rede for kritikken av disse forestillingene og verdiene på en nyansert måte. Dessuten både styres og begrenses lærebokskrivingen av læreplanen, noe som viser seg i hvor like disse bøkene tross alt er. Men bøkene er uansett utgitt, og har i denne artikkelen status som likestilte eksempler.

Artikkelen er en tekstorientert analyse av lærebøker som leses uavhengig av lærerveiledninger, observasjoner eller intervjuer med forfatterne, lærere eller elever. Tekstene unders $\emptyset$ kes slik de foreligger, og artikkelen handler utelukkende om dem.

\section{Del 1: Bakgrunn, problemstilling, fagfelt og metode}

Etter at Norge ble dømt i FNs menneskerettighetskomité (2004) og den europeiske menneskerettighetsdomstolen i Strasbourg (2007) fordi KRLE-faget vanskeliggjorde reell religionsfrihet i skolen, ble regelverket rundt faget skjerpet:

Opplæringsloven legger til grunn at undervisningen skal vere objektiv, kritisk og pluralistisk. Det innebcerer at den skal vcere saklig og upartisk og at de ulike verdensreligioner og livssyn skal presenteres med respekt. I undervisningen skal det ikke vare forkynnelse eller religionsutøvelse. Likeverdige pedagogiske prinsipper skal legges til grunn. Det innebcerer at alle religioner og livssyn skal behandles på en faglig og sakssvarende måte ut fra sitt scerpreg og mangfold (fra læreplanen for KRLE, www.udir.no/klo6/ RLE1-02/Hele/Formaal - lest 04.03.2018).

Selv om det har gått mange år siden dette ble formulert, er det mye som tyder på at disse kravene er innfridd i svært vekslende grad (Fuglseth 2014). For å finne ut om undervisningen er «saklig og upartisk», kan en ta i bruk observasjon eller intervju, men i denne artikkelen er metoden altså lærebokanalyse. Læreb $ø$ kene er etterprøvbare kilder til hva som vektlegges i store deler av skolens undervisning. De kan i noen tilfeller innta rollen som ekstralærer eller undervisningsplanlegger, og vi vet at mange lærere opplever det betryggende og tidsbesparende når læreboka leder undervisningen (Bråten 2014, Tallaksen og Hodne 2014).

Jeg har valgt to av de mest sentrale begrepene fra læreplansitatet ovenfor, og formulerer følgende problemstilling: Bidrar læreb $ø$ kene til en undervisning som er både kritisk og upartisk? Eller sagt på en annen måte: Er lærebøkene kritiske? Er de i så fall like kritiske hele tiden, uansett hvilke religioner eller livssyn de tar for seg? Det er dette jeg fors $\emptyset$ ker å finne ut i artikkelen.

\section{Lærebokforskning og religionskritikk}

Dagens lærebokforskning henger sammen med et $\emptyset$ kende behov for kunnskap om lærebøker etter at den statlige godkjenningsordningen etter 111 år ble 
avviklet i 2000. De første forskningsprosjektene skulle kartlegge kvalitet i vid forstand, ofte med fokus på språklig tilgjengelighet og multimodalitet (se f.eks. Skjelbred og Aamotsbakken 2010, Maagerø og Winje 2010 - tidligere eksempler er Johnsen 1997,1999).

Andre undersøkelser har hatt andre innfallsvinkler, og vi vet i dag mer om lærebøkene enn vi gjorde før 1997: Njål Skrunes har gjennomført bredt anlagte analyser av religionslærebøkene som kom i kjølvannet av ny læreplan i 1997, med vekt på blant annet toleranselæring og hvordan forholdet mellom kristendom og islam ble fremstilt (2010b, se også Skrunes 2010a). Nevnes kan også Ann Midttuns analyse av en lærebok for ungdomstrinnet som viser hvordan islam presentert $\mathrm{i}$ 《biter og deler» går på bekostning av et helhetlig bilde (Midttun 2014). Suzanne Thobro har påvist hvordan endringer i lærebøkene reflekterer endringer $\mathrm{i}$ 《den norske buddhistdiskursen», og har også analysert hvordan kart som viser religioners geografiske utbredelse påvirker forståelsen av hva religion er. Bengt-Ove Andreassen har for $\emptyset$ vrig skrevet en avhandling og flere artikler om lærebøkene som brukes i lærerutdanningen. To sentrale spørsmål gjelder hvordan lærebøkene håndterer religiøse konflikter og hvordan selve konseptet religion forstås (Andreassen 2008, 2014). Selv har jeg kartlagt hvordan hinduismen i større grad enn buddhismen er utsatt for othering («andregjøring», Kitzinger 1996), noe som kan slå ut i eksotisering så vel som demonisering, samt ufaglige forenklinger, som overdreven vektlegging av likheter eller ulikheter religionene imellom (Winje 2013).

Disse analysene avdekker i ulik grad diskurser som vanskeliggjør et saklig og kritisk blikk på religioner (Georgakopoulou og Goutsos 2004, Shi-xu 2012). Fram til 1960-årene fantes det lærebøker i kristendomskunnskap som i fullt alvor formidlet at hedningenes problem var at de ville gå fortapt dersom de ikke omvendte seg og ble kristne (Winje 2011). I løpet av1970-1980-årene endret lærebøkene karakter, og hedningenes problem gikk over fra mangel på kristen tro til mangel på humanistiske ideer og verdier. Dermed endret også begrunnelsen for misjon seg. En konsekvens av denne endringen ble at «hedningene» ikke lenger ble fremstilt som vantro, men som inhumane. ${ }^{2}$

\section{Valg av lærebøker}

Det er ingen tungtveiende grunner til å velge KRLE-bøkene for 5. årstrinn til akkurat denne undersøkelsen, det viktigste er å få et tekstutvalg som både er fyldig nok til å være representativt, og begrenset nok til å kunne håndteres. Ifølge

2 Eksempler: Før endringen: «(...) hedningene gjør seg andre guder av tre og stein» (Berggrav 1938, gjengitt i Winje 2011:145). Etter endringen: «[Misjonæren William] Carey mente at den religionen hedningene i India hadde, var fryktelig. Han så at barn ble ofret i elva Ganges. Enker ble brent levende sammen med mannens lik. Når vogna til avguden Jagganath i Orissa kjørte gjennom gatene, kastet mange mennesker seg under hjulene» (Andersen 1976:47, gjengitt i Winje 2011:149). 
læreplanen skal elevene lære om religionskritikk på ungdomstrinnet, noe som skulle tilsi at artikkelen burde ha tatt for seg lærebøker for 8. -10. trinn. På den annen side er det interessant å unders $\emptyset$ ke om og eventuelt hvordan religionskritikk utøves i læreb $\emptyset$ kene uavhengig av de aldersspesifikke kompetansemålene.

Jeg kjenner til fem lærebøker som er i bruk på dette trinnet:

- Berg, Mari Ann, Børresen, Beate og Nustad, Peder (2006): Vi i verden 5 (Cappelen)

- Engen, Dagrun A. A., Eriksen, Eli-Anne V., Iversen, Ragnhild, Næss, Even, Skarpeid, Jon og Sværen, Jenny H. (2009): Inn i livet 5 (Samlaget)

- Bondevik, John Harald, Borgersen, Anne og Scjelderup, Ariane (2010): Vivo 5-7 (Gyldendal)

- Hodne, Hans, Syse, Henrik og Sødal, Helje K. (2011): Du og jeg 5 (Høyskoleforlaget)

- Børresen, Beate, Hammer, Aina og Skrefsrud, Thor-André (2017): KRLEboka 5-7 (Cappelen Damm)

Vivo 5-7 og KRLE-boka 5-7 er skrevet for alle de tre årene på mellomtrinnet. I sistnevnte har jeg holdt meg til de kapitlene som er markert som lærestoff for 5. årstrinn, mens jeg i Vivo 5-7, der lærestoffet ikke er disponert etter årstrinn, har lest partier som er sammenlignbare med dem jeg har lest i de andre bøkene.

\section{Metode}

Ifølge Susanne Knudsen arbeider jeg på poststrukturalistisk vis (Knudsen 2010:179): «Forskellige forskere henter inspiration fra forskellige teorier og sætter dem sammen i en begrundet eklekticisme». Hun sier også at diskurs (analyse), dekonstruksjon og diversitet er grunnelementer i denne pragmatiske metoden, som i utgangspunktet er svært enkel. Den kan i teorien deles i tre faser, selv om de ofte overlapper hverandre i praksis. Den første fasen kan karakteriseres som eksplorativ (unders $\emptyset$ kende) eller abduktiv (i motsetning til deduktiv og induktiv, jf. Laursen, u.å., se også Check og Schutt 2012). I dette ligger at jeg begynner på analysen uten å ta utgangspunkt i etablert teori, men med en problemstilling som angir blikkretning. I dette tilfellet stopper jeg først opp ved alle utsagn som påpeker kritikkverdige forhold eller antyder en religionskritisk holdning. Etter hvert som jeg finner mønstre (gjentagelser, kontraster, etc) i det empiriske materialet (lærebøkene), formulerer og reformulerer jeg hypoteser.

Selv om den varierer fra sak til sak, er hovedgrepet i neste fase å identifisere og kartlegge spenninger i teksten, ofte i form av motsetningspar, og selv om de bare er delvis formulerte: En effekt av en positiv språklig ladning er at motpolen virker negativt ladd, enten det er tilsiktet eller ikke. Når én religion kommenteres positivt og en annen religion ikke kommenteres i det hele tatt, blir effekten 
at sistnevnte får en negativ ladning. I fase 3 oppsummerer jeg ved så langt som mulig å beskrive den diskursen jeg har avdekket.

\section{Del 2: Analyse}

Under den første gjennomlesningen av de fem lærebøkene fant jeg ingen eksempler på det jeg hadde forventet, nemlig kritisert religion, kritiserte religiøse konsepter eller kritisert religiøs praksis. Under neste gjennomlesning la jeg likevel merke til at flere av bøkene i forbindelse med visse temaer, særlig kjønnsroller, hadde en tendens til å virke kritiske uten å si tydelig at de var det. ${ }^{3}$ Jeg formulerte dette, slik jeg iakttok og forsto det, som en hypotese (1, se nedenfor). Da jeg etter hvert ble klar over at lærebøkene ved andre anledninger tok opp lignende forhold, men helt uten å antyde at de var diskutable, formulerte jeg en ny hypotese (2). Et eksempel er hvordan Vi i verden 5 omtaler de første kristne martyrene generelt og Den hellige Agnes spesielt. Læreboka videreformidler her en forståelse av kyskhet og død med mer, uten å forholde seg til at disse har endret seg siden 3-400-tallet. ${ }^{4}$

I tillegg fant jeg ytterligere fire gjennomgående mønstre som var tydelige nok til at jeg kunne formulere hypoteser. Hypotese 3 og 4 gjelder riktignok ikke direkte religionskritiske utsagn eller mangel på slike. De gjelder likevel forhold med et kritisk potensial, da positive vinklinger (her med vekt på relevans og historisitet) på noen religioner kan få andre til å virke mindre positive.

De to siste hypotesene er ikke unders $\emptyset$ kt nærmere i denne artikkelen, blant annet på grunn av omfanget. De nevnes likevel her, da hypotese 6 med fordel kan undersøkes i en egen artikkel, og det dessuten er forsket en del på dette feltet (Aamotsbakken og Winje 2010a, 2010b, 2010c). Hypotese 5 har vist seg å være mer kompleks og tidkrevende enn forventet. I den videre analysen følger jeg altså opp de fire første hypotesene.

- Hypotese 1: Lærebøkene kan antyde at det er kritikkverdige sider ved religioner, for eksempel ved å nevne dem - ofte som om de var nøytrale saksopplysninger, og ikke problematiske forhold.

- Hypotese: 2: Lærebøkene kan unnlate å antyde eller kommentere mulige kritikkverdige forhold på noen som helst måte.

- Hypotese 3: Lærebøkene kan ved hjelp av oppgaver og annet få fram at noen religioner er aktuelle og relevante.

3 Jeg skriver noen steder som om bøkene er aktører, et litterært virkemiddel som er forholdvis enkelt å bruke og å avkode.

$4 \ll$ De kristne som nektet å følge kravet fra [keiser] Decius [om å ofre til de romerske gudene og til keiseren selv], ble drept. Dermed ble de martyrer og helter for de kristne» (Berg 2006:31). «(...) Dommeren var først vennlig mot henne [Agnes]: - Glem Jesus og gift deg med en av disse stolte unge mennene, sa han til henne. Agnes nektet. Hun ville ikke høre om noen andre menn enn Jesus Kristus (...) Agnes brydde seg ikke om hva dommeren sa. Ja, hun virket nesten glad ved tanken på at hun kanskje måtte dø for sin tro.» (ibid.:30). 
- Hypotese 4: Lærebøkene kan fortelle om religioner på en slik måte at det virker som om de samsvarer med historie- og naturvitenskap.

- Hypotese 5: Lærebøkene kan, ved hjelp av faglig nivå og presisjon, signalisere at noen religioner er spesielt viktige.

- Hypotese 6: Lærebøkene kan ved hjelp av ordvalg, metaforer og andre språklige grep sannsynliggjøre eller svekke de andre hypotesene.

\section{Hypotese 1:}

Lærebøkene kan antyde at det er kritikkverdige sider ved religioner, for eksempel ved å nevne dem - ofte som om de var nøytrale saksopplysninger, og ikke problematiske forhold

Blant temaene som hyppigst utsettes for kritikk i lærebøker om religion, er kjønnsroller og manglende likestilling. Et eksempel er Vi i verden 5, som blant annet tar for seg religiøse bygninger, og i den forbindelse tematiserer gudstjeneste, bønn og tilbedelse i tilknytning til kirken (Berg 2006:14ff), moskeen (ibid.:54ff), synagogen (ibid.:60), buddhisttemplet (ibid.:69ff) og hindutemplet (ibid.:78ff). Kristendomsdelen (fagstoffet om kirkebygget og hva som foregår der) er mer omfattende enn de andre delene, så her finner jeg fire utsagn om kjønnsroller. De er formulert som saksopplysninger, ikke som vurderinger:

1 Kvinner kunne ikke døpe i urkristendommen

2 Paulus sa at mannen skulle bestemme over kvinnen

3 Også i dag mener mange kristne at kvinner ikke skal døpe

4 I Den norske kirke kan kvinner bli prester og døpe

I tillegg finner jeg ett utsagn som gjelder islam og ett som gjelder jødedom:

5 Kvinner er atskilt fra menn i moskeen

6 Kvinner er i mange synagoger atskilt fra menn

I tekstene om hindu- og buddhisttempler nevnes ikke kjønnsroller.

Jeg leser disse utsagnene som religionskritikk basert på verdier som samsvarer med dagens likestillingsdiskurs. Utsagn 4 er det eneste positive utsagnet her, og læreboka får på den måten sagt at dagens norske kirke står i kontrast til både urkristendommen (utsagn 1 og 2), den katolske kirken og andre kristne trossamfunn som ikke godtar kvinnelige prester (utsagn 3), islam (utsagn 5) og jødedom (utsagn 6). Denne tolkningen er kanskje ikke tilsiktet, men slik teksten foreligger, er det dette den formidler.

Vivo 5-7 tar også opp kjønnsroller i jødedom og kristendom, med vekt på fordeling av oppgaver og ekteskapets status i jødedommen (Bondevik 2010:59). Boka konstaterer at kvinner og menn ifølge jødedommen har forskjellige oppgaver i hjemmet, og at ekteskapet mellom mann og kvinne er den beste måten å ordne seg på. Den peker altså på kjønnsroller som egentlig er diskutable, men 
legger ikke opp til diskusjon eller kritikk.

Du og jeg 5 nevner forskjellene mellom kvinner og menn i moskeen (Hodne 2011:16), mens KRLE-boka 5-7 på side 226f tar opp både kvinners og menns påkledning på en måte som synes å anerkjenne både muslimers praksis (enten de kler seg slik eller slik) og kritikernes synspunkter (Børresen 2017:226f). I tillegg skal elevene arbeide med en ganske omfattende oppgave om ulike forståelser og praksiser i tilknytning til klær - også denne om både kvinner og menn (ibid.: 235).

KRLE-boka 5-7 sier også litt om klasse- og kasteinndelingen i det indiske samfunnet, men heller ikke her formuleres kritikk ut over det antydende (ibid.: 240). Det er først når boka nevner at dalitene (de kasteløse) «er svært fattige og blir ofte undertrykt» (ibid.), at teksten er tydelig kritisk, men tematikken følges ikke opp her heller.

Eksemplene vi har sett på så langt, gjelder hovedsakelig etiske forhold, men det er også eksempler på at teologiske synspunkter utsettes for kritikk. KRLEboka 5-7 er i så måte alene om å fortelle at det er ulike syn på Koranen og islam (Børresen 2017:192):

Mange mennesker mener at islam alltid har eksistert, fordi de tror at Allah og Koranen

har voert til bestandig. De som forsker på religion, mener at islam oppsto på 6oo-tallet

KRLE-boka 5-7 er også alene om å nevne ahmadiyya, en trosretning eller snarere reformbevegelse, som ikke anerkjennes som islam i islamsk lovgivning (ibid.:199). Den presenteres på en halv side rett etter et avsnitt om troen på profeter, som er den fjerde av islams sju trossannheter. For en tilhenger av ahmadiyya er dette en logisk plassering, siden Ahmad, som grunnla denne retningen på 1800 -tallet, betraktes som profet. For en tradisjonell muslim er Ahmad imidlertid en falsk profet, siden han kom etter Muhammed, som var «profetenes segl», altså den siste profet. Den halve siden er formulert slik at ahmadiyya framstår som et offer (hvilket bevegelsen er, sett i lys av moderne menneskerettigheter) og islam som kritikkverdig religion.

\section{Hypotese 2:}

\section{Lærebøkene kan unnlate å antyde eller kommentere mulige} kritikkverdige forhold på noen som helst måte.

Hypotese 2 gjelder, i motsetning til hypotese 1, tekstpartier som ikke antyder at noe er problematisk eller kritikkverdig - selv om mange i dag mener det, og selv om det kan bryte med skolens verdigrunnlag. Vivo 5-7 forteller for eksempel om den buddhistiske skikken med barnemunker uten å problematisere den (Bondevik 2010:278). Og når eposet Ramayana refereres i Inn i livet 5, nevnes det ikke at heltens hustru, Sita, i sentrale varianter av diktverket går på bålet - 
altså begår selvmord - fordi hun mistenkes for utroskap (Engen 2009:74f). Når samme bok skal gi et eksempel på en hadith, velges en atypisk fortelling om Profetens omsorg for hunder, uten at læreboka sier noe om alle hadithene som forbyr hundehold (ibid.:113).

I Vi $i$ verden 5 er et bilde av Burak, fabeldyret som tok med seg Muhammed på hans nattreise, trykt to steder (Berg 2006:42,49), mens bildeforbudet kobles på islams første søyle, trosbekjennelsen. Forbudet gjøres dermed gjeldende for avbildninger av Gud, men tolkes ikke eksplisitt om å avbilde «engler, profeter og sahaba (Muhammads følgesvenner)», slik det anbefales i Kildesamling til KRL (Rasmussen og Thomassen 1999:269). I Du og jeg 5 er et lignende motiv gjengitt, men her er ikke forbudet nevnt i det hele tatt (Hodne 2011:10). Det er det heller ikke i KRLE-boka5-7, selv om den er illustrert med en miniatyr fra 1808 som viser Muhammed (omgitt av ild, så ansiktstrekkene ikke synes) sammen med nærmere 50 følgesvenner. Når bildeforbudet etter manges mening brytes i disse bøkene, er det så langt jeg kan se påkrevd å enten føye seg og fjerne de aktuelle bildene, eller å ta opp problematikken i læreboka. Det kan være gode pedagogiske grunner til å vise slike bilder, som er typiske for visse perioder i islams historie, men læreren/ læreboka bør også vite at disse periodene ofte forstås som forfallstider.

Fra kristendommens historie har vi allerede nevnt martyridealet, som ikke problematiseres i Vi i verden 5 (Berg 2006:28ff). Samme bok fremstiller også kristne asketer ukritisk (ibid.:36ff). Når Vivo 5-7 forteller at Frans fra Assisi kuttet all kontakt med familien sin, er det som del av en idyllisk fortelling om denne helgenen, som i vår tid ville kunne karakteriseres som en fanatiker (Bondevik 2010:129):

(...) Etter dette [en åpenbaring som førte til at Frans pusset opp en gammel, falleferdig kirke] ga Frans fra seg alt han eide, og ble munk. Foran biskopen og andre viktige menn tok han klærne av seg, ga dem tilbake til faren og sa: «Før kalte jeg deg far. Nå sier jeg 'Vår Far i himmelen'.» Frans gikk ikke i kloster, men vandret rundt som tiggermunk, hjalp syke og fattige og fortalte dem om Jesus. (...)»

Fra samme bok henter jeg et siste eksempel på hvordan lærebøkene noen ganger tar opp problematiske forhold som om de ikke var problematiske (ibid.:51):

\section{Israel er en jødisk stat}

Jødene har en spesiell historie knyttet til landet Israel, som ble grunnlagt som en jødisk stat $i$ 1948. Israel er de eneste landet $i$ verden som kaller seg jødisk. Selv om Israel er en jødisk stat, bor det også kristne, muslimer og andre i landet.

Selv om disse eksemplene er svært forskjellige, har de én ting felles, nemlig at læreboka styrer utenom potensielt konfliktstoff. Samtidig går de glipp av en nøktern tilnærming til problematiske sider ved religionenes tekster og praksi- 
ser, og de får heller ikke benyttet sjansen til å se nærmere på ulikheter.

Lærebøkenes fortelling om oldkirken er et kapittel for seg. Som i mange kirkehistoriske fremstillinger beskrives dogmedannelsen som om det fantes en sannhet i forkant av kirkemøtene, og at denne ble forsvart mot vranglærere. Stridighetene gjaldt særlig Jesus. Det var - enkelt sagt - tre hovedsyn.:

1 Det som ble det katolske synet: Jesus er sann Gud og sant menneske. Dette var «den rette lære», som de oldkirkelige trosbekjennelsene forsvarer, den athanasianske (400-500-tallet) til og med ved hjelp av trusler (artikkel 2): «Enhver som ikke bevarer denne [læren] hel og uforfalsket, vil uten tvil gå evig fortapt $\gg .5$

2 Det gnostiske synet: Jesus er Gud, ikke (noe vanlig) menneske. Det er en forenkling å si at denne kristendomsformen lever videre i dag, men enkelte elementer, blant annet forestillingen om reinkarnasjon, kan vi møte i Kristensamfunnet, som er et dogmefritt trossamfunn med cirka 2500 norske medlemmer, hvorav de fleste forholder seg til antroposofiske forestillinger og praksiser (Rudolf Steiners menneskesyn).

3 Det arianske synet: Jesus er en skapning, ikke noe vanlig menneske, men heller ikke Gud. I dag finner vi et lignende syn hos blant andre Jehovas vitner.

Noen få hundreår senere ble det formulert nok en lære om Jesus, nemlig den som fremgår av Koranen og hadith. Jesus er her ikke guddommelig, men han er unik. Jesus er ifølge islam den eneste personen i tillegg til Adam som Gud har skapt av jord. Han er ikke unnfanget ved samleie - altså jomfrufødsel. Han døde ikke på korset selv om det så slik ut for dem som var til stede. Han lever skjult videre.

Når Vi i verden 5 (Berg 2006:34) forteller om dogmedannelsen, er stridighetene tonet kraftig ned:

Konstantin fikk dem [biskopene fra Romerriket som deltok på kirkemøtet i Nikea år 325] til å bli enige om hva de kristne mente i de viktigste spørsmålene. Biskopene lagde en kort oversikt som sa hva kristendommen var.

Her sies det ikke noe om den maktkampen som faktisk fant sted, og heller ikke noe om hvordan kristendommen 100 år senere ble statsreligion og den allmenne (katolske) kirken ble den eneste tillatte og ansvarlig for å forfølge annerledes troende. Lærebøkene bidrar slik til å legitimere en seiglivet kirkediskurs der én kristendomsform er sann og de andre er falske.

Keiseren bestemte også at Jesu fødsel skulle feires i forlengelsen av en førkristen solfest nær vintersolverv, et påfunn som har gitt Jehovas vitner en av sine viktigste symbolsaker. Selv om Inn i livet 5 bruker mye plass på høytider,

5 De oldkirkelige bekjennelser (kirken.no/globalassets/kirken.no/om-troen/kristen-tro/oldkirkelige_bekjennelser2.pdf - lest 22.11.2017). 
nevnes ingen slike alternative forståelser (Engen 2009:43ff). Her formidler imidlertid Vivo 5-7 en riktignok sterkt forenklet, men mer religionskritisk versjon (Bondevik 2010:126):

Mot slutten av 300-tallet ble kristendommen den eneste tillatte religionen $i$ Romerriket. Festdager for de gamle romerske gudene ble byttet ut med festdager for Jesus, Maria og andre helgener. Det var viktig for folk at de ikke mistet festene, selv om de fikk en ny religion. For at keiseren ikke skulle få folk imot seg, byttet han bare innhold i feiringene.

\section{Hypotese 3:}

\section{Lærebøkene kan ved hjelp av oppgaver og annet få fram at noen religioner er aktuelle og relevante}

Både lærebøker og undervisningen for øvrig legger i mange fag opp til å inspirere og engasjere. Det er sjelden noe galt i det, men slike didaktiske grep bør tones ned når det handler om religion - $\mathrm{i}$ hvert fall hvis de fungerer appellativt.

Aktualisering av religionsfaglig stoff finner så vidt jeg kan se sted $\mathrm{i}$ to av de i alt 17 《Tenk selv»-oppgavene i Du og jeg 5 . I kapittelet om buddhisme bes elevene om å ta stilling til fråtsing (ibid.: 21), og i kapittelet om jødedom bes de om å ta stilling til tre «Visdomsord fra Hillel» (ibid.:102):

- «Den som fremhever sitt eget navn, mister det.»

- «Døm aldri din neste før du er i hans sted.»

- «Jo mer velstand, desto flere bekymringer.»

- Tenk selv

- Hva tenker du om visdomsordene fra Hillel?

- Synes du han har rett?

Et annet grep som synes å skulle gi elevene en opplevelse av religioners relevans, er å la dem bruke tid sammen med kildetekster. De kan for eksempel få i oppgave å finne fram i Bibelen (ibid.: 97), skrive dikt, tegne eller formulere personlige tanker i møte med teksten, noe KRLE-boka 5-7 særlig legger opp til i forbindelse med buddhismen (Børresen 2017:311). I samme bok knyttes buddhistiske idealer relativt tett til leserne (ibid.:305), som også oppfordres til å forestille seg at de har levd flere liv (ibid.:299):

2. En bodhisattva har medlidenhet med alt som lever.

a. Lag forslag til hvordan vi kan vise medlidenhet med alt som lever.

(...)

4. I buddhistisk lære er tanken om karma og gjenfødsel sentralt.

a. Hva kan være bra med å ha flere liv?

b. Hva kan være dårlig med å ha flere liv?

c. Hva ville du gjort annerledes hvis du fikk et liv til?

d. Hva ville du skulle vært likt i ditt neste liv? 
Filosofisk samtale er en arbeidsform som har vært relativt tungt inne i religionslærebøkene de siste årene. Arbeidsformen brukes ofte til å aktualisere og etablere nærhet til fagstoff: I forbindelse med buddhismen spørres det for eksempel i en bildetekst (ibid.:287): «Har du mange ting hjemme? Blir du lykkelig av tingene?» Her stiller læreboka et allment spørsmål som ikke har behov for noen religiøs kontekst. Når det likevel kobles på buddhismen, er det i samsvar med en tendens, en «vending i diskursen» (Thobro 2009:23), som kan henge sammen med at buddhismen oppfattes som en lite religiøs religion: «siddharta

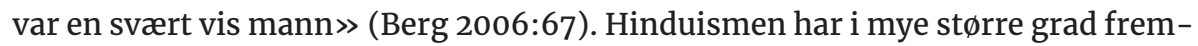
stått som morsom og fargerik, og lærebøkene har bekreftet det eksotiske preget, som her i KRLE-boka 5-7 (Børresen 2017:263):

- Tenk deg at du har deltatt på feiringen av Holi.

- Hva opplevde du? Skriv dagbok.

I samme bok stilles for $\emptyset$ vrig mer generelle filosofiske spørsmål med hinduismen som utgangspunkt (ibid.:249):

- Vishnu kjemper mot det onde.

- Hvor kommer det onde fra?

Til dette vil jeg knytte to kommentarer: For det første mener jeg at det - uansett hvilken religion det handler om - er problematisk at elevene her inviteres inn i det ondes problem i stedet for å lære om det ondes problem. For det andre er det prisverdig at en lærebok gjør en «innvandrerreligion» til utgangspunkt for samtaler om et fellesreligiøst tema som det ondes problem. Det bryter med tendensen til å la kristendom (og til dels jødedom) være alene om å representere religion i sin alminnelighet (Winje 2008). De samme to kommentarene gjelder også et «filosofisk hjørne» i samme bok med overskriften «Gud» i et kapittel om jødedom - selv om jødedom i norske lærebøker ofte faller sammen med kristendom på en litt uklar måte (Winje 2008, Børresen 2017:157):

Mange som tror på Gud, tror at Gud passer på dem. Hvordan kan Gud passe på menneskene når det er så mange mennesker som har det vondt?

\section{Hypotese 4:}

Lærebøkene kan fortelle om religioner på en slik måte at det virker som om de samsvarer med historie-og naturvitenskap

Når ti år gamle elever spør om en religiøs fortelling er sann eller ikke, lurer de gjerne på om hendelsene fant sted slik de er beskrevet, det være seg i Bibelen eller en annen hellig bok. «Riktig svar» er at dette er et trosspørsmål, men at det også er et spørsmål om dokumentasjon og empiri, og at religionenes fortellinger kan forstås på flere måter. I det følgende gjør jeg rede for hvordan lærebøkene forholder seg til spørsmålet om sannhet på denne konkrete måten. 
Lærebøkene veksler tilsynelatende usystematisk mellom å gjenfortelle innholdet i hellige tekster som om fortellingene er historisk troverdige, og å gjøre rede for hva forskningen sier om kildenes alder og opphav. Vi i verden 5 er i så måte typisk:

- På side 97 drøftes fedrehistorienes historisitet.

- På side 117 poengteres det at evangeliene er ulike.

- På side 119 står det: «Hva Jesus gjorde tidligere i livet er usikkert», en setning som indirekte sier at evangelienes jesusfortellinger er historisk troverdige.

- På samme side står det at både Lukas og Matteus forteller om Jesu fødsel.

- På side 120 gjenfortelles Lukas' beretning om Jesu fødsel som om den er en historisk hendelse.

I Inn $i$ livet 5 er et eget kapittel viet «Hellige skrifter» (s. 88-124), der over 20 sider handler om Bibelen. Leseren får først vite at: «Bibelen fins i flere forskjellige utgaver. Den bibelen du skal lære om i dette kapittelet, er den som blir brukt i Den norske kirke» (Engen 2009:91). På side 96 finner vi en kortfattet redegjørelse for et historisk bibelsyn, uten at andre bibelsyn nevnes. Kapittelet inneholder også sitater og resymeer av bibelfortellinger, men de kommenteres ikke historisk. Både Vi i verden 5 og Inn $i$ livet 5 gir altså teoretisk og generell informasjon om Bibelens historisitet, men ingen av dem gjennomfører noen historisk-kritisk lesning av konkrete tekster.

Vivo 5-7 og Du og jeg 5 er mer entydige, da ingen av dem drøfter dateringsspørsmål, og begge plasserer Abraham og Moses med flere langs tidslinjer, som om det var snakk om historiske hendelser (Bondevik 2010:103, Hodne 2011:62f). På en annen tidslinje er Jesu fødsel lagt til år 5 f.Kr. (Bondevik 2010:125). Verken elevbok eller lærerveiledning forklarer hvorfor, men når lærebokforfatterne lanserer et annet fødselsår enn det kristen tidsregning baseres på, kan det virke som om de forholder seg til sikrere kilder enn Bibelen. På samme tidslinje står det ved år 30: «Jesus døde, sto opp og for opp til himmelen», på side 111 drøftes antallet vismenn som kom med gaver til barnet, og på side 119 brukes fortellingen om kvinnene ved graven retorisk for å styrke oppstandelsens troverdighet.

Et lignende grep finner vi i en bildetekst på side 150 i Du og jeg 5: « Ingen vet helt sikkert hvor Jesus holdt Bergprekenen, men det ble bygd en kirke ved det fjellet der mange tror han holdt den» (Hodne 2011:150). Her får leseren høre om usikkerhet når det gjelder tid og sted på en slik måte at det ikke levnes tvil om at Jesus holdt denne prekenen på et konkret fjell.

Når det gjelder andre religioner enn kristendommen, har lærebøkene færre sider til rådighet. Når Vivo 5-7 presenterer Koranen på side 110, inntar den et 
muslimsk innenfraperspektiv, uten at andre mulige syn nevnes. Dette til forskjell fra KRLE-boka 5-7, som presenterer to motstridende syn på side 192 (sitert under overskriften «Hypotese 1» ovenfor). På side 115 i Vivo 5-7 finner vi fem linjer om buddhismens hellige tekster. Her făr leseren vite at de er mange, at de er gamle, og at mange av dem handler om Buddhas liv. Med unntak av et kort sitat uten kildehenvisning, går resten av de fire sidene om buddhismens hellige tekster med til å gjenfortelle en jataka (fortelling fra et av Buddhas tidligere liv). Fortellingen er på alle vis relevant for femte årstrinn, men eventyrtrekk og høy underholdningsverdi gjør den lite egnet som eksempel til drøfting av tekstens eventuelle historisitet. Ifølge Inn i livet 5 har hinduismen «flere hellige tekster enn noen annen religion» (ibid.:117). Likevel avgrenses temaet til to sider, som riktignok er informative, men på et svært generelt nivå. Det leseren i praksis får vite noe om, er et mantra, Ramayana, Mahabharata, og de to eposenes usikre datering.

KRLE-boka 5-7 fokuserer noe mer på historisitet når det gjelder tekster fra hinduisme og buddhisme. To eksempler er vedaenes alder (Børresen 2017:242) og en oppgave som lyder: «Forskere i dag er ikke helt enige om nøyaktig når Buddha levde. Kan du tenke deg hvorfor det er slik?» (ibid. :285). Andre steder forholder denne boka seg til eksempelvis Mosesfortellingen (ibid.:104f) som om den var historisk sann. Alt i alt virker sannhetsspørsmålet tilfeldig håndtert i de valgte bøkene.

\section{Del 3: OpPSUMmering Og KONKLUSJON}

Bidrar så lærebøkene til en undervisning som er både kritisk og upartisk (jf. den innledende problemstillingen)? Det kan i lys av denne gjennomgangen virke som om de kvier seg for å være (for) kritiske, og at det derfor er litt tilfeldig når og hvordan de kritiserer religionene de omhandler. Likevel kan det virke som om kritikken følger et visst mønster, noe som innebærer at den kan oppleves som partisk. Basert på et førsteinntrykk satte jeg opp seks hypoteser, hvorav fire er sannsynliggjort i analysen (se tabell nedenfor).

Det er kun i forbindelse med den første hypotesen at jeg har sett på lærebøkenes eventuelle negative vurderinger av religioner eller elementer i religioner. I forbindelse med de tre andre hypotesene har jeg kartlagt positive vurderinger og holdninger til de samme religionene i de samme lærebøkene, enten i form av å unngå kritiske utsagn, eller ved å fremstille religionene som attraktive og troverdige. 


\begin{tabular}{|c|c|}
\hline $\begin{array}{l}1 \text { Lærebøkene kan antyde at det er kritik- } \\
\text { kverdige sider ved religioner for eksempel } \\
\text { ved å nevne dem - ofte som nøytrale og ikke } \\
\text { problematiske forhold }\end{array}$ & $\begin{array}{l}2 \text { Lærebøkene kan unnlate å gjøre leserne } \\
\text { oppmerksomme på kritikkverdige sider ved } \\
\text { religioner ved å ikke kommentere dem på noen } \\
\text { som helst måte }\end{array}$ \\
\hline I tilknytning til hinduismen & I tilknytning til hinduismen \\
\hline Daliter (kasteløse) i India & Enkeselvmord som ideal \\
\hline I tilknytning til jødedommen & I tilknytning til buddhismen \\
\hline Ekteskapet som religiøst ideal & Buddhistiske barnemunker \\
\hline Kjønnsroller i synagogen & I tilknytning til jødedommen \\
\hline I tilknytning til kristendommen & Jerusalem \\
\hline Kjønnsroller i kirken (tidligere tider) & I tilknytning til kristendommen \\
\hline I tilknytning til islam & Kristen forfølgelse av annerledes troende \\
\hline Kjønnsroller i moskeen & Askese som kristent ideal \\
\hline Kvinners påkledning & Martyrium som kristent ideal \\
\hline Koranens/islams alder & I tilknytning til islam \\
\hline Ahmadiyya & Synet på hunder i den muslimske verden \\
\hline $\begin{array}{l}3 \text { Lærebøkene får ved hjelp av oppgaver og } \\
\text { annet fram at noen religioner er aktuelle og } \\
\text { relevante }\end{array}$ & $\begin{array}{l}4 \text { Lærebøkene kan fortelle om religioner på en } \\
\text { slik måte at det virker som om de samsvarer } \\
\text { med historie- og naturvitenskap }\end{array}$ \\
\hline I tilknytning til hinduismen & I tilknytning til kristendommen \\
\hline Skrive holi-dagbok & Fedrehistorien fortelles som om den er \\
\hline Tenke igjennom det ondes problem & historisk troverdig \\
\hline I tilknytning til buddhismen & Jesu fødsel er en historisk hendelse \\
\hline Unngå fråtsing & Bergprekenen fortelles som om den er historisk \\
\hline Tenke seg at en lever flere liv & troverdig \\
\hline Ta stilling til / vurdere flere liv & \\
\hline $\begin{array}{l}\text { Lage forslag tIl hvordan vi kan vise medilden- } \\
\text { het med alt som lever }\end{array}$ & \\
\hline Unngå å ha for mange ting & \\
\hline I tilknytning til jødedommen & \\
\hline Si seg enig med jødiske visdomsord om & \\
\hline dømme andre & \\
\hline eie for mye & \\
\hline I tilknytning til kristendommen & \\
\hline $\begin{array}{l}\text { Tenke igjennom det ondes problem } \\
\text { Lese i Bibelen }\end{array}$ & \\
\hline $\begin{array}{l}\text { Tenke igjennom behovet for martyrer og } \\
\text { helgener }\end{array}$ & \\
\hline
\end{tabular}

Helt til sist vil jeg peke på tre tendenser i det begrensede materialet som er gjennomgått i denne artikkelen (se tabellen ovenfor): For det første er buddhismen den eneste religionen jeg ikke har sett noe til i forbindelse med hypotese 1, altså den eneste som ikke er utsatt for direkte kritikk eller antydning til kritikk. Det er også buddhismen som oftest er fremstilt som relevant for elevene (hypotese 3). For det andre er det islam som får mest kritisk oppmerksomhet (hypotese 1). Islam er også den eneste religionen som aldri presenteres som relevant for leserne. For det tredje er det kun i forbindelse med kristendommen at fortellinger tidfestes som historiske begivenheter, og det er i forbindelse med denne religionen at flest kritikkverdige forhold verken nevnes eller kommenteres på andre måter (jf. hypotese 2). 


\section{LITTERATUR}

Aamotsbakken, Bente og Winje, Geir (2010a). «Lesing av fagtekster i RLE» i Skjelbred, Dagrun og Aamotsbakken, Bente (red): Lesing av fagtekster som grunnleggende ferdighet. Oslo: Novus.

Aamotsbakken, Bente og Winje, Geir (2010b). «Nærhet og distanse. Elevers lesing i RLE på 8. årstrinn» i Tidsskriftet FOU i praksis nr. 1/2010.

Aamotsbakken, Bente og Winje, Geir (2010c). «Å lese om islam og andre emner i RLE på 5. årstrinn» i Skjelbred, Dagrun og Aamotsbakken, Bente (red): Faglig lesing $i$ skole og barnehage. Oslo: Novus.

Andersen, Leif Ansgar (1976): De møtte Kristus. Oslo: Luther.

Andreassen, Bengt-Ove (2008). «Konfliktperspektiver i religionsundervisning og religionsdidaktikk - en bredere og bedre tilnærming til religion? » i Acta Didactica Norge 8/2008.

Andreassen Bengt-Ove (2014). «A reservoir of symbols: On the conceptualisation of 'religion' in Introductory books for RE in Teacher Education in Norway > $\mathrm{i}$ Andreassen, Bengt-Ove og Lewis, R. James (red.): Textbook Gods. Genre, Text, and Teaching Religion Studies. Sheffield: Equinox

Berg, Mari Ann, Børresen, Beate og Nustad, Peder (2006): Vi i verden 5. Oslo: Cappelen. (2010).

Berggrav, Eivind (1938, 6. oppl. 1953). Katekismen etter Dr. Martin Luther. Norsk skoleutgave med øvinger i kunnskap om kristendom. Oslo: Gyldendal.

Bondevik, John Harald, Borgersen, Anne og Schjelderup, Ariane (2010). Vivo 5-7. Oslo: Gyldendal.

Bråten, Oddrun M. H. (2014). «Bruk av lærebøker i RLE.» i Fuglseth, Kåre (red.): RLE $i$ klemme. Ein studie av det erfarte RLE-faget. Bergen: Fagbokforlaget.

Børresen, Beate, Hammer, Aina og Skrefsrud, Thor-André (2017). KRLE-boka 5-7. Oslo: Cappelen Damm.

Check, Joseph og Schutt, Russel K. (2012). Research Methods in Education. Los Angeles: Sage.

Engen, Dagrun A. A., Eriksen, Eli-Anne V., Iversen, Ragnhild, Næss, Even, Skarpeid, Jon og Sværen, Jenny H. (2009). Inn i livet 5. Oslo: Samlaget.

Georgakopoulou, Alexandra og Goutsos, Dionysis (2. utg. 2004). Discourse Analysis. An Introduction. Edinburgh: Edinburgh University Press.

Hodne, Hans, Syse, Henrik og Sødal, Helje K (2011). Du og jeg 5. Kristiansand: Høyskoleforlaget.

Jehovas vitner. Forkynnere av Guds rike (1993). Brooklyn, New York: Watch Tower Bible and Tract Society of Pennsylvania.

Johnsen, Egil B. (1997). Kunnskapens tekster. Jakten på den gode larebok. Oslo: Universitetsforlaget.

Johnsen, Egil B. (1999). Lœrebokkunnskap. Innføring i sjanger og bruk. Oslo: Tano Aschehoug. 
Kitzinger, Celia og Wilkinson, Sue (1996). «Theorizing representing the other» $\mathrm{i}$ Kitzinger, Celia and Wilkinson, Sue (red.): Representing the Other. A Feminism and Psychology Reader. London: Sage.

Knudsen, Susanne V. (2010). «Poststrukturalistiske tilgange» i: Knudsen, Susanne V. og Aamotsbakken, Bente (red.) Teoretiske tilncrminger til pedagogiske tekster. Kristiansand: Høyskoleforlaget.

Laursen, Martin Holmgaard (u.å.). «Abduktive læreprocesser» i Abduktiv.dk (www. abduktiv.dk/abduktive-læringsprocesser/ - lest 01.01.2018)

Maagerø, Eva og Winje, Geir (2010). «Multimodalitet og læremidler» i Skjelbred, Dagrun og Aamotsbakken, Bente (red): Lesing av fagtekster som grunnleggende ferdighet. Oslo: Novus.

Midttun, Ann (2014). «Biter og deler av islam» i Norsk pedagogisk tidsskrift 5/2014.

Nicolaisen, Tove (2015). Hindubarn i grunnskolens religions- og livssynsundervisning. Egengjøring, andregjøring og normalitet. Oslo: Universitetet i Oslo.

Rasmussen, Tarald og Thomassen, Einar (red.) (1999). Kildesamling til KRL. Oslo: Nasjonalt læremiddelsenter.

Shi-xu (2012). «A multicultural approach to discourse studies» i Gee, James Paul og Handford, Michael (red.). The Routledge Handbook of Discourse Analysis. London/ New York: Routledge

Skjelbred, Dagrun og Aamotsbakken, Bente (red): Faglig lesing i skole og barnehage. Oslo: Novus.

Skrunes, Njål (2010a). Lœrebokforskning. En eksplorerende presentasjon med særlig fokus på Kristendomskunnskap, KRL og Religion og etikk. Oslo: Abstrakt.

Skrunes, Njål (2010b). Toleranselæring og læereboktekster. Oslo: Abstrakt.

Tallaksen, Inger M. og Hodne, Hans (2014). «Hvilken betydning har læremidler i RLE-faget?» i Norsk pedagogisk tidsskrift 5/2014.

Thobro, Suzanne Annett (2014). «Cartographic representations of religion(s)» i Andreassen, Bengt-Ove og Lewis, R. James (red.): Textbook Gods. Genre, Text, and Teaching Religion Studies. Sheffield: Equinox.

Thobro, Suzanne Annett (2009). «Endringer i representasjoner av buddhisme. En analyse av norske lærebøker i perioden 1948-2006» din. Tidsskrift for religion og kultur 4/2009.

Winje, Geir (2008). «Lærebøkene i KRL - hva har skjedd på ti år?» i Norsk teologisk tidsskrift nr1/2008.

Winje, Geir (2011). «Når 'de Andre' rykker nærmere. Om 1900-tallets lærebøker i kristendomskunnskap» i Skjelbred, Dagrun og Aamotsbakken, Bente (red): Norsk larebokhistorie III. En kultur- og danningshistorie. Oslo: Novus.

Winje, Geir (2013). «Respekt, toleranse, dialog? Holdninger til østlige religioner i de første lærebøkene i KRL» i Askeland, Norunn m.fl. (red): Lœreboka. Studier av ulike loereboktekster. Oslo: Akademika. 